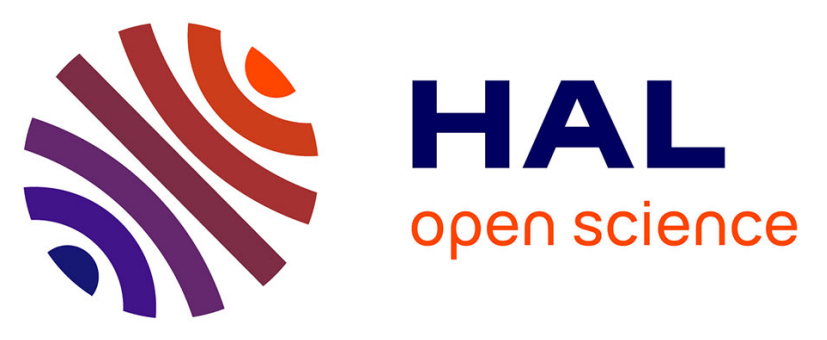

\title{
An experimental ethnoarchaeology and analytical approach to fire-related management strategies in a hunter-fisher-gatherer society from the southern tip of Tierra del Fuego (Argentina)
}

\author{
Albert Garcia-Piquer, Joan-Miquel Lozano, Ramiro Javier March, Jordi \\ Estevez-Escalera
}

\section{To cite this version:}

Albert Garcia-Piquer, Joan-Miquel Lozano, Ramiro Javier March, Jordi Estevez-Escalera. An experimental ethnoarchaeology and analytical approach to fire-related management strategies in a hunterfisher-gatherer society from the southern tip of Tierra del Fuego (Argentina). Ethnoarchaeology, 2018, Ethnoarchaeology of fire and combustion residues: Current approaches, 10 (2), pp.121-140. 10.1080/19442890.2018.1510609 . hal-01879980

\section{HAL Id: hal-01879980}

\author{
https://hal-univ-rennes1.archives-ouvertes.fr/hal-01879980
}

Submitted on 28 Sep 2018

HAL is a multi-disciplinary open access archive for the deposit and dissemination of scientific research documents, whether they are published or not. The documents may come from teaching and research institutions in France or abroad, or from public or private research centers.
L'archive ouverte pluridisciplinaire HAL, est destinée au dépôt et à la diffusion de documents scientifiques de niveau recherche, publiés ou non, émanant des établissements d'enseignement et de recherche français ou étrangers, des laboratoires publics ou privés. 


\title{
An Experimental Ethnoarchaeology and Analytical approach to fire-related management strategies in a Hunter-Fisher-Gatherer society from the southern tip of Tierra del Fuego (Argentina) ${ }^{11}$
}

\author{
Albert García-Piquer ${ }^{\mathrm{a}, \mathrm{b}}$, Joan-Miquel Lozano ${ }^{\mathrm{a}}$, Ramiro J. March ${ }^{\mathrm{c}}$, Jordi Estévez-Escalera ${ }^{\mathrm{a}, \mathrm{b}}$ \\ ${ }^{\text {a }}$ Department of Prehistory, Autonomous University of Barcelona (UAB), Catalonia, Spain \\ ${ }^{b}$ Laboratory of archaeozoology, Autonomous University of Barcelona (UAB), Catalonia, Spain \\ ${ }^{\mathrm{C}}$ CREAAH, UMR 6566 du CNRS Université de Rennes 1, Rennes Cedex, France
}

CONTACT Albert García-Piquer alberto.garcia.piquer@uab.cat Department of Prehistory, Autonomous University of Barcelona (UAB), Catalonia, Spain

Supplemental data for this article can be accessed https://doi.org/10.1080/19442890.2018.1510609.

\begin{abstract}
This paper presents a synthetic overview of the results of a multidisciplinary approach -archaeological, experimental and ethnographic- that provides new insights into the fire-related management strategies (from firewood procurement to fire use and cleaning activities) adopted by Yamana groups. We bring to the fore the significance of recent results from a chemical, GC-MS and GC-C-IRMS analysis of combustion residues recovered from Túnel VII and Lanashuaia I, two shell-midden excavated in the framework of several SpanishArgentinean, Experimental Ethnoarchaeology projects developed in Tierra del Fuego Island (Argentine). The molecular and fatty acids isotopic composition allow characterizing the different combustion structures from the perspective of intensity or food processing, informing also about post-depositional factors. Results allow for a critical evaluation of ethnographic sources and thus of direct observation.
\end{abstract}

Keywords: Residue analysis, Fatty acids, Isotope, Fire structures, Experimental approach, Ethnoarchaeology, Hunter-Gatherers, Tierra del Fuego

\section{Introduction}

Archaeological remains of the use of fire and fire-related activities are central elements of hunter-fisher-gatherers research. The identification of different kinds of "fire structures" (March 1995) allows assessment of site duration (March et Ferreri 1989; March et al 1989; March 1995) or interpretation of intra-site archaeological spatial distribution patterns and "living floors" (Leroi-Gourhan et Brezillon 1972; March et al. 2006; Leesch et al. 2010; Leesch et Bullinger 2012; Julien et Karlin 2014; March et al. 2017). Nevertheless, as with other aspects of socioeconomic activities and

\footnotetext{
${ }^{1}$ This is an Accepted Manuscript of an article published by Taylor \& Francis Group in Ethnoarchaeology on 27/08/2018, available online: http://www.tandfonline.com/10.1080/19442890.2018.1510609.
} 
behavior when dealing with prehistoric hunter-gatherer societies, most archaeological evidence is difficult to recognize and interpret, taking the form of a scattered or concentrated association of combustion residues. Previous ethnoarchaeological research has focused on hearths as central elements to infer intra- or inter-site spatial patterns (Binford 1978; Yellen 1977), but rarely on the experimental or analytical study of fires structures or in their formation processes (March et al. 2014; Mallol and Henry 2017).

From 1986 on, Spanish-Argentinean ethnoarchaeological research has been carried out in the Beagle Channel of Tierra del Fuego, Argentina (Piana et al. 1992; Estévez and Vila 1995; see Vila and Estévez 2017 for additional bibliography). An Experimental Ethnorchaeology approach was proposed in order to test and improve an archaeological holistic methodology for obtaining data about the main social relationships and management strategies using an ethnographically well-known case (Estévez and Vila 2007). Hunter-fisher-gatherers of Tierra del Fuego Island were chosen for this experiment (the detailed reasons for this choice have been published elsewhere: Estévez and Vila 2007). Confronting ethnographic sources with archaeological evidence of the same group allows verifying archaeological theory and methodology. Moreover, the direct nature of archaeological data has proven to be useful also in reviewing the biased ethnographic information that results both from the subjective position of ethnographers and from the sporadic nature in time and space of their observations (e.g. Estévez et al. 2002; Mameli et al. 2005; Terradas et al. 1999; Colonese, et al. 2011).

This research did incorporate and develop the experimental and analytical approach to the study of fire structures (March 1988, 1989, 1990, 1992, 1999; March and Wünsch 2003) that try to join different aspects of the archaeological data related to fire to contrast the ethnographic and archaeological records. This approach is oriented to reconstruct the social management of fire and its significance for the management strategies of global hunter-fisher-gatherer groups. In this sense many different analyses converge to reconstruct the use of fire at the Túnel VII and Lanashuaia I sites. This paper emphasizes the results of chemical, GC-MS and GC-C-IRMS analysis of the combustion residues recovered from two Yamana archaeological sites. Archaeological, experimental and ethnographic data will be later contrasted to discuss the whole firerelated work processes from firewood procurement to fire use and cleaning activities. 
These data have been extensively assembled and published (Orquera and Piana 1999). A brief review of Yamana fire-related management strategies can be found in the Supplementary materials (S1).

\section{Materials and methods}

\section{Archaeological context}

The sites of Túnel VII (TVII), excavated during the years 1989-1993, and Lanashuaia I (LI), excavated during 1996-1996 and 2005, were occupied contemporaneous with ethnographic descriptions. They are located in the northern shore of the Beagle Channel, Tierra del Fuego, Argentina (Fig. 1). The excavations were to explore the relationship between the social organization and the articulation in space of the production, distribution and consumption processes (Vila and Estévez 2000). Therefore, the excavation method focused on the internal structure of the site and the site-formation processes. On the one hand, large area excavation was carried out referring the finds to a 3D coordinated net of $0.50 \mathrm{~m} 2$ squares. Remains larger than 1 $\mathrm{cm}$ were coordinated and the whole sediment was sieved with a $1 \mathrm{~mm}$ mesh. On the other hand, specially developed excavation methodology was implemented in order to isolate and extract each of the stratigraphic subunits resulting from the characteristic rapid deposition of Tierra del Fuego shell middens (Orquera and Piana 1992) as well as for recording hearth structures (Wünsch 1991).

Túnel VII is placed $\left(54^{\circ} 49^{\prime} 15^{\prime \prime} \mathrm{S}, 68^{\circ} 09^{\prime} 20^{\prime \prime} \mathrm{W}\right)$ on the slope of a small cove $(40 \times 20 \mathrm{~m})$, between the shore of a pebble beach and the nearby Nothofagus forest line (Orquera 1995: 47). Surrounded by escarpments, natural sediment deposition determined the site-formation history. Excavation an area of $32 \mathrm{~m}^{2}$ revealed an area with a ring of shell middens surrounding a deep central area of dark humus. The periphery was composed of the repeated deposition of food waste, mainly shells, but also of charcoal, flakes and lithic debris. Moreover, small concavities located at the periphery of the central area are interpreted as postholes, enclosing an approximately circular area of $3.5 \mathrm{~m}$ diameter (Estévez and Vila, 2006). These structures are typical of the ethnographically documented Yamana huts (see Piana and Orquera 2010). In addition, the site was radiocarbon and dendrochronologically dated to the end of the $18^{\text {th }}$ century and the end of the $19^{\text {th }}$ century (Piana and Orquera 1995). 


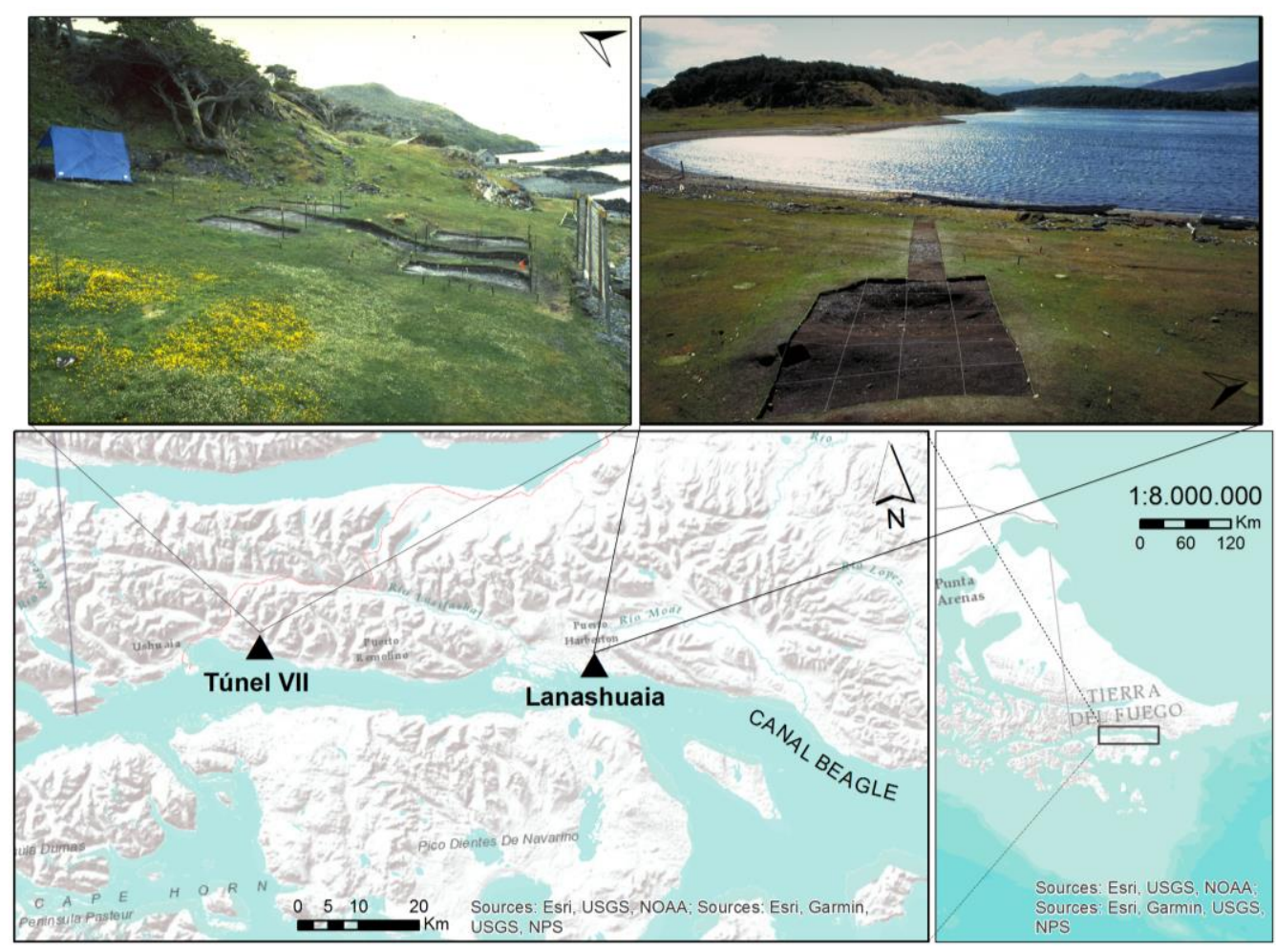

Figura 1. Map with the location of the sites Túnel VII and Lanashuaia I on the Beagle Channel, Tierra del Fuego Island (Argentina)

The main microstratigraphic sub-units (Orquera 1995), were: shell sub-units (Conchero, C); shell dominated earths (Tierra conchiferas, TC); black earths (Humus, $\mathrm{HU}$ ); and pebbles (Guijarros, GU). Two types of combustion structures were found in TVII (Wünsch 1991; Orquera 1995; Piquè 1999). On the one hand, several combustion structures (EC after the Spanish acronym) consisting of small areas of heat altered mollusks shells were identified on top of shell middens, especially at peripheral subunits. On the other hand, eleven structured combustion areas (AC after the Spanish acronym) were identified by the stratigraphic coherence of burnt soil layers and distinguished from other associations of combustion residues produced by emptying and cleaning of primary hearths. Some of these combustion structures AC were reduced and shallow, but others were deeper and wider (Fig. 2). However, all of them were simple surface hearths showing a consistent stratigraphic yellowish (top) to blackish (bottom) sediment, and to a lesser extent of greyish (center) to brownish (periphery) shells. With the exception of $\mathrm{AC} 1$ and $\mathrm{AC} 4$, all the fireplaces were lighted on a prepared surface of small pebbles few centimeters deep. Few macro residues of combustion and charcoal 
fragments were recovered from inside the $\mathrm{AC}$, except in two cases (Table 1; Piquè 1999).
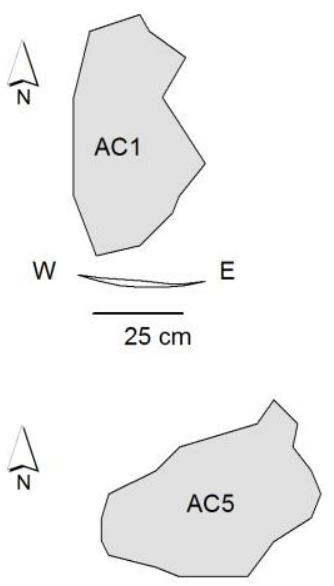

W

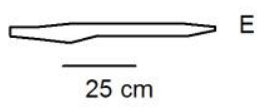

$\sqrt{N}$

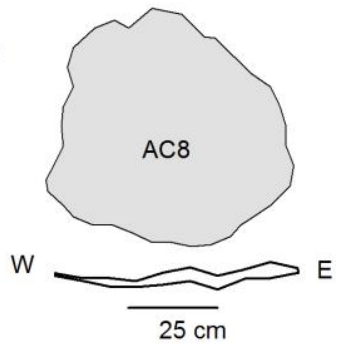

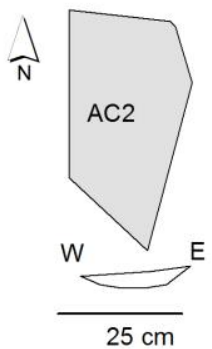
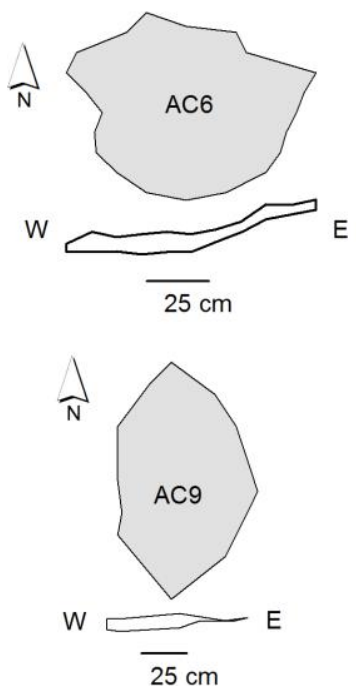
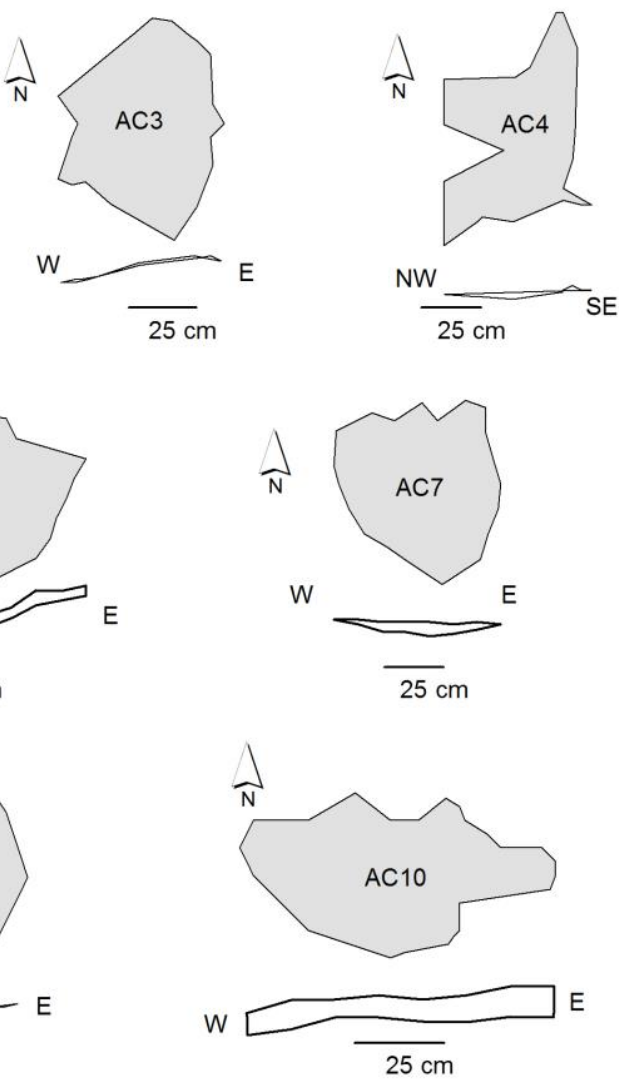

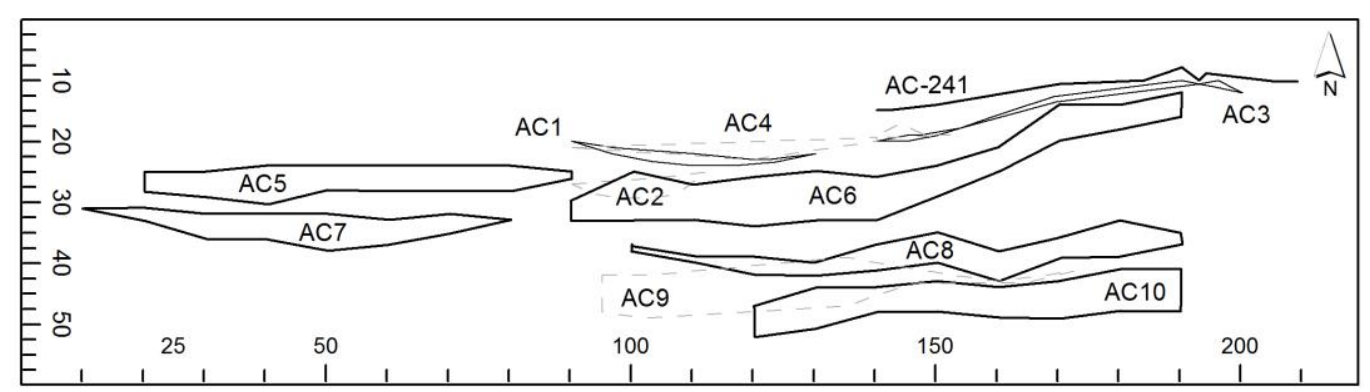

Figura 2. Above: ground-plan of Túnel VII main combustion areas. Below: vertical section of the habitation area $(\mathrm{Y}$ coordinate $=150 \mathrm{~cm})$ showing the overlapping of the central combustion structures. Dotted lines indicate combustion areas at different $\mathrm{Y}$ coordinates.

Thin layers of non-burned soil identified between various AC indicated the successive re-use of the central area, and in one case (AC6) there was a clear re-use of a previous combustion area AC8 (Fig. 3b). This evidence permitted to propose at least nine or ten short successive occupation episodes (A to $\mathrm{J}$-the last episode, after which the concavity resulting from these occupations was covered by more waste tossed from 
other nearby occupation centers) during an 80-year span, providing the opportunity to perform a stratigraphic assemblage of peripheral shell midden subunits (Estévez and Vila 2006; Vila et al. 2009).

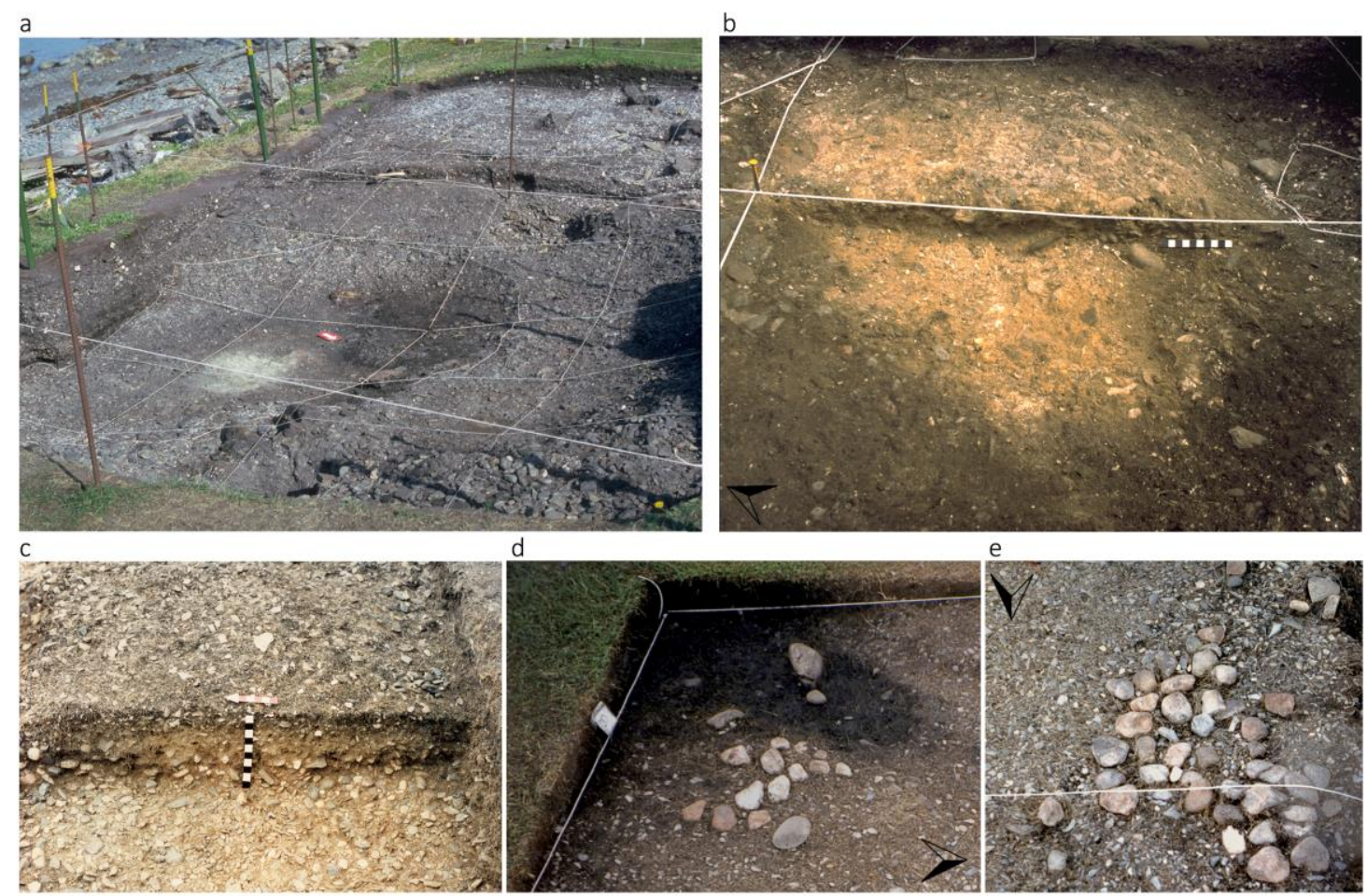

Figura 3. Túnel VII final phase of excavation, revealing the earlier combustion area AC1 (a) and two overlapped fireplaces in the central area of TVII, AC6 and AC8 (b). Combustion structures of Lanashuaia I: E-W vertical section of the central hearth AC3 (c); the Southwestern heated pebbles accumulation over a spot of fatty oily soil (d); the Eastern heated pebble accumulation, without visible fatty oily residue (e).

Contextual and spatial analysis of archeological remains and the study of combustion residues and hearths have been approached by means of statistical distribution algorithms (Wünsch 1995; Estévez and Clemente Conte 2013; GarcíaPiquer and Estévez 2018), shell remains analysis (Verdún-Castelló 2011) and the stratigraphic correlation of shell midden sub-units in the immediate surroundings (Vila et al. 2009). The microstratigraphy and site formation processes have been contrasted by means of stone and bone refitting and skeletal re-articulations (Verdún et al. 2010). Micromorphological analyses were done for two samples of the whole sediment column on two spots on the south section of the site and for seven samples of the fireplaces (Balbo et al. 2010; Villagran et al. 2011). 
Tabla 1. Summary of the chemical and archaeological data from Túnel VII combustion areas discussed.

\begin{tabular}{lllllllll}
\hline Sample & Context $^{\mathrm{a}}$ & EP $^{\mathrm{b}}$ & Season $^{\mathrm{c}}$ & Length $^{\mathrm{d}}$ & $\mathrm{NC}^{\mathrm{e}}$ & Temp $^{\mathrm{g}}$ & Intensity $^{\mathrm{h}}$ & Fatty acid $^{\mathrm{i}}$ \\
\hline AC10 & AC10(B470) & AB & W & S & 1 & $500-600$ & MEDIUM & MM \\
AC9 & AC9(B467) & C & W & S & 1 & - & LOW & MM \\
AC7 & AC7(B440) & D & SU-AU & S-L & 0 & - & HIGH & FISH \\
AC8 & AC8(B425) & E & W & L & 5 & $500-600$ & MEDIUM & MM \\
AC6 & AC6(B395) & F & SP & L & 18 & MIXED & LOW & FISH \\
AC5 & AC5(B365) & G & AU-W / & S & 125 & $350-450$ & LOW & VEGETAL \\
& & & SP-SU & & & & & \\
AC4 & AC4(B290) & H & SP/SU & S-L & 8 & $350-450$ & MEDIUM & FISH \\
AC3 & AC3(B290) & H & SP/SU & S-L & 36 & - & MEDIUM & FISH \\
AC2 & AC2(B290) & H & SP/SU & S-L & 6 & - & MEDIUM & FISH/MM \\
AC1 & EC1(B290) & H & SP/SU & S-L & - & - & MEDIUM & FISH \\
- & AC1(B241) & J & SU-AU & S & 5 & - & - & -
\end{tabular}

a Archaeological context of the sample. Bracketed acronyms correspond to the field subunit, all of them located in sectors II, II-III or III.

bOccupation episode from Túnel VII

c Seasonality of the occupation episode based on malacological (Colonese et al. 2011; Verdún 2011), ichthyological (Juan-Muns 1992) and bird (Mameli and Estévez 2004) remains: W - Winter, SP - Spring, SU - Summer, AU Autunm. Backslash " $\$ " indicates alternative assumptions.

${ }^{d}$ Length of the occupation episode based on the intensity of firewood procurement document (Piquè 1999) and frequencies of archaeozoological remains (Estévez and Vila 2006): S - Short, L - Long.

e Number of charcoal macro-remains recovered from inside the combustion areas (Piquè 1999).

${ }^{\mathrm{f}}$ Temperature $\left({ }^{\circ} \mathrm{C}\right)$, based on micro-morphology analysis of fireplaces (Villagran et al. 2011).

$\mathrm{g}$ Intensity of the combustion, based on the thermal degradation of the $\mathrm{n}$-alkane fraction.

$\mathrm{h}$ Interpretation proposed concerning the use of each fireplace based on fatty acids results. MM = Marine Mammal. i No sample was taken from this fireplace (the first excavated).

Lanashuaia I is located $60 \mathrm{~km}$ east of TVII (54 $52^{\prime} 48.79^{\prime \prime} \mathrm{S}, 67^{\circ} 16^{\prime} 22.77^{\prime \prime}$ $\mathrm{W}$ ), in a very different microenvironment with a shallow relief. LI is part of a remarkable alignment of several shell midden structures along the coastline of the isthmus between the inner and outer Cambaceres bays (Piana et al. 2000). The excavation of $114 \mathrm{~m}^{2}$, revealed the whole area of a ring-shaped shell midden and a large surrounding external area (Verdún et al. 2015). Like in TVII, marks of postholes and the spatial distribution analyses of the archeological remains delineate a circular structure of c. 3-4 m (Fig. 4). The entrance to the hut was facing the beach (to the west) and was located on an old storm berm. The central area was originally slightly dug out, taking advantage of the natural relief of the beach (Verdún et al. 2015). Unlike TVII, evidence of LI suggests a single occupation (Verdún et al. 2015).

Excavation methodology and stratigraphic analysis was performed in the same way as TVII. Three main combustion areas were identified at the site. The central hearth (AC3) was probably burnt in two consecutive events on the very base of the concavity. 
Heated sediment is very thick ( 3 to $4 \mathrm{~cm}$ ), reaching c. $1 \mathrm{~m}$ in diameter (Fig. 3c). The focus of the heat was elongated $(80 \times 50 \mathrm{~cm})$. A second hearth, at the hut entrance (AC1), was burnt for a part directly on the pebble beach and for the other part on a slight deposition of shells (C15). It was later covered by a thicker deposition of shells (C10) which allowed the preservation of the ashes of AC1. A final one (AC-B11) is an open-air fireplace located east of the rear shell midden and surrounded by a stone knapping area (Verdún et al. 2015). It was lighted directly on pebbles from the palaeobeach. The structure consisted of a surface of 4-cm thickness of thermally altered pebbles laying over an accumulation of fatty soil. No charcoals were recovered.

Other small structures of combustion, mainly spots of burnt soil, are EC60, EC60-2 and EC2. The latter is placed on a layer of heat-altered, small pebbles (c. $1 \mathrm{~cm}$ width). These structures are surrounded by other non-structured combustion residues, mainly yellowish sediments and heat-altered, small pebbles embedded in carbonaceous matrix, coming from hearth-cleaning. All these associations of combustion elements were covered by the major shell midden (C5) and subsequent depositions. Finally, three heated pebble accumulations were found outside the habitation area: one at the East, behind the hut and at the bottom of the shell accumulation (Fig. 3e). Two more heated pebble accumulations -one to the South and another the Southwest outside the hut- were surrounded by a blackish greasy soil (Fig. 3d). Two similar but unburnt pebble accumulations were also found outside the hut to the north.

\section{Sample Selection and Analytical Methodology}

Twelve archaeological soil samples from TVII site have been analyzed (see Table S14). AC1, AC2 and AC2G (grey and yellow sediment respectively), AC3 and AC4, all of them over subunit B290 and thus associated to the penultimate occupation (H); AC5 (subunit B365, occupation G); AC6 (B395, occupation F); AC8 (B425, occupation E); AC7 (B440, occupation D); AC9 (B465, occupation C); and AC10 (B470, occupation B). Additionally, a control sample of non-heated soil (TUS) was also analyzed. Four soil samples from LI were analyzed: LANA3, central hearth AC3; LANA1, AC1 at the hut entrance; LANA 2, structure AC-B11 on the rear of the hut; and LANA 4, from the greasy soil of the Southwestern heated pebbles accumulation. Furthermore, a sample of heated pebbles of the Eastern accumulation (behind the shell- 
midden ring of LI) was selected to analyze the residues of the penetration of oils during the heating.

Lipid fractions of soil and pebble samples were extracted and collected according to previously established methods (Aceves, et al., 1988; McCarthy and Duthie 1962). Samples were then analyzed by gas chromatography-mass spectrometry (GC/MS) and, in the case of heated pebbles, gas-chromatography-combustion-isotope ratio mass spectrometry (GC-C-IRMS). A detailed description of the method can be found in the Supplementary materials (S2).

\section{Results and discussion}

Concerning chemical study of TVII and LI structure combustions, lipid distributions are consistent with expected results. A detailed description of the results and a graphical summary of each lipid fraction and sample results can be found in the Supplementary materials (S3-13).

\section{Combustion areas samples}

Most of the samples show significant thermal degradation of n-alkanes (Table S14). Degradation is particularly stronger in AC7 and weaker in AC5, AC6, AC9 and LANA3. Aliphatic hydrocarbons distribution is characteristic of higher plant cuticular waxes (Eglinton and Hamilton, 1967; López-Martínez et al., 2006), and is interpreted as the consequence of fuel wood contribution. A high carbon preference index (CPI) supports this interpretation. Alcohols and sterols presence is more irregular. Among the latter, $\beta$-sitosterol (plant-origin), cholesterol (animal-origin) and coprostanol (a faekal biomarker) are the most abundant. $\beta$-sitosterol is present in all the samples except for AC6. Coprostanol results from anaerobic degradation of organic matter by earthworms in humus rich soil (McCalley et al., 1981; Grimalt et al., 1990), indicating postdepositional processes. 


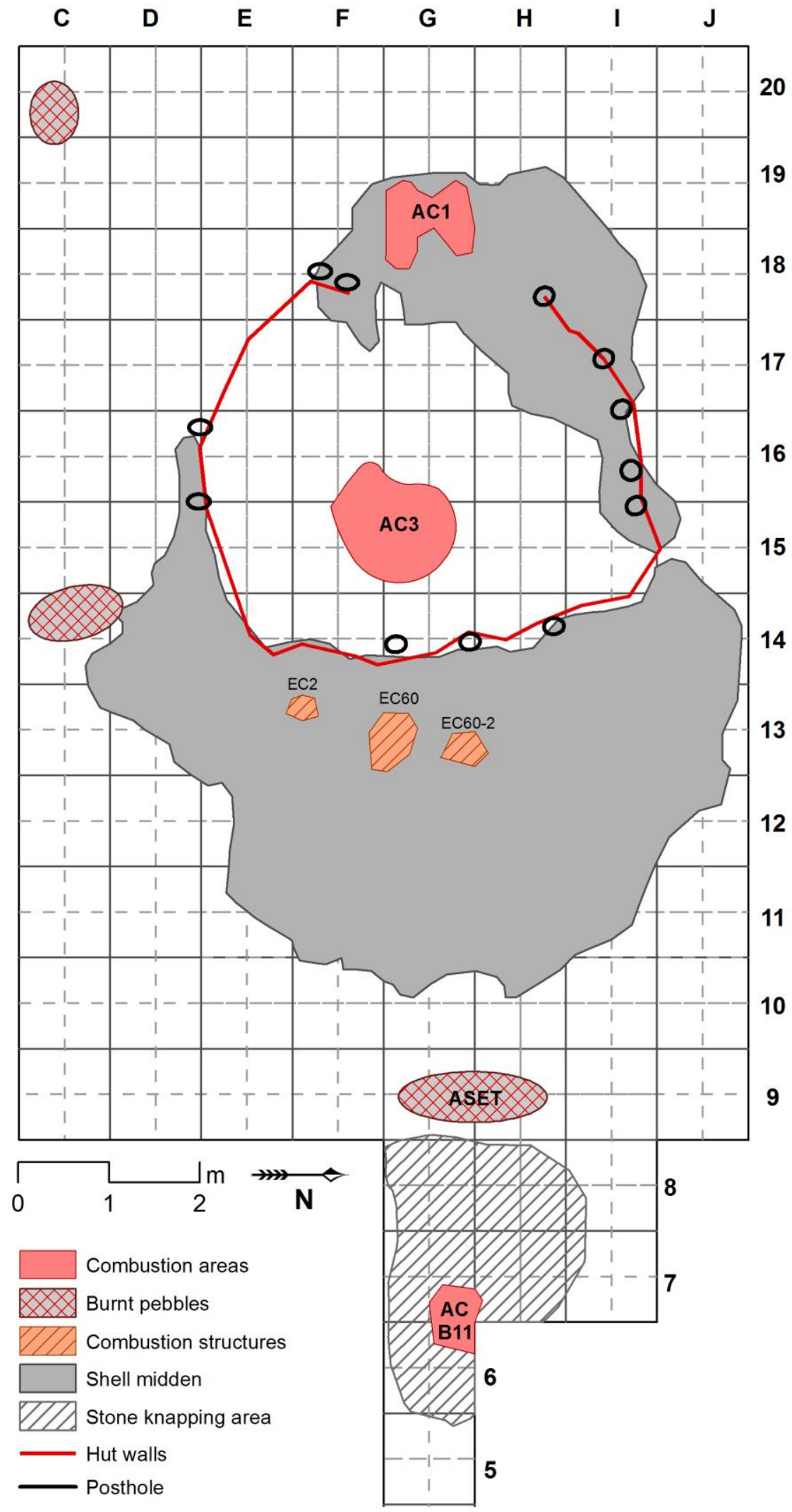

Figura 4. Spatial representation of the habitation area and the main structures identified at Lanashuaia I site. 
Results show considerable variability of fatty acids. However, two clusters have been detected. AC1-6, TUS and LANA1 samples exhibit high relative proportion of C18 unsaturated fatty acids compared to the major peak of the chromatogram. Prominent among them is octadec-7-enoic acid, generally attributed to algae origin (Chuecas and Riley, 1969; Harvey et al., 1987). Abundance of C18:1 isomers has been suggested as an indicator of fish oil presence (Malainey et al 2001, Eerkens 2005). Presence of polyunsaturated fatty acids (PUFA's) is interpreted in the same direction. Coherently, archaeozoological analysis has identified an important quantity of fish remains both in TVII, particularly in the two last occupations (Juan-Muns 1993), and LI (Verdún et al. 2015). However, other sources of C18 unsaturated fatty acids are possible in soil samples (Grimalt and Saiz-Jimenez 1989). Indeed, their presence is detected in low levels in all the samples, including non-burnt TUS sample. On the other hand, relative high frequencies of squalene and presence of diploptene acids in TVII samples (AC2, AC8, AC9 and AC10) and in the central hearth of Lanashuaia (LANA3) have been detected. Those acids are very low or virtually absent in the other samples. They could be interpreted as marine mammal biomarkers. Marine mammal remains, particularly pinnipeds, have been recovered in high frequencies in both sites (Estévez et al. 1995; Verdún et al. 2015).

TVII provides the opportunity to study diachronic use of fire in a recurrent social space. First should be noted an important variability in the chemical signatures. Is difficult to characterize each structure based on chemical analysis. This is probably due to the non-specialized use of most of these combustion structures, especially in the case of those located in the center of the habitation area. In addition, a "palimpsest" nature of these fireplaces has been detected, even in ostensibly very short occupations (Piquè 1999), with repeated heating/cooling cycles observed in micromorphological samples (Villagran et al. 2011). Likewise, a non-specialized used of fire is expected based on ethnographic and archaeozoological data both at TVII and LI (Estévez et al. 2001; Mameli and Estévez 2004; Verdún et al. 2015).

Soil micromorphology study of TVII (Balbo et al. 2010) clarified site formation process and confirmed the previously identified nine (at least) short successive occupation episodes (Estévez and Vila 2006). We could therefore isolate different successive activities of residue deposition and establish intra-site patterns of space 
management (Estévez and Clemente 2013; Estévez and Vila 2006; García-Piquer and Estévez 2018). As expected in a Yamana context, a general trend is coastal resource exploitation: intertidal shellfish, fish and marine mammals (Orquera and Piana 1999). Notwithstanding, variability has been observed during the successive short different occupation episodes in the site of TVII (Estévez and Vila 2006). First and foremost, bird and fish consumption increase as marine mammal remains decrease (Juan-Muns 1993; Mameli and Estévez 2004). Cetacean remains are also more abundant in TVII earliest occupations (Estévez and Vila 2006).

Fatty acids results concur with previous data. Samples from the penultimate occupation $\mathrm{H}$ ( $\mathrm{AC} 1, \mathrm{AC} 3, \mathrm{AC} 4)$ show a predominance of fish consumption, while samples from earlier occupations (AC10 and AC9) show a predominance of marine mammal consumption. Nevertheless, variability is observed. Moreover, sample AC5 shows a predominance of plant origin fatty acids. Further research should attempt to clarify these issues.

Additionally, results provide new information regarding TVII occupation patterns (Table S14). Previous seasonal data was proposed based on exploitation of Nacella magellanica (Colonese et al. 2011); presence of migratory fish remains or juvenile birds (Juan-Muns 1993; Mameli and Estévez 2004); and intensity of firewood procurement, documented through the relative frequencies of high/low quality wood fuel taxa per occupation (Piquè 1999). Micromorphological analysis (Villagran et al. 2011) concluded that recent AC4 and AC5 fireplaces reached moderate temperatures $\left(350-450^{\circ} \mathrm{C}\right)$. In opposition, early AC8 and AC10 fireplaces comprised shells fragments burnt at temperatures above $500-600^{\circ} \mathrm{C}$ indicating high-intensity combustion structures. For their part, AC6 showed a mixed composition supporting the stratigraphic suggestion that AC6 is superimposed on AC8. Results concerning thermal degradation of n-alkanes (i.e. intensity of combustion) are consistent with previous data. Unfortunately, it is not possible to discern whether intensity relates to duration of fire or to temperatures reached. However, cross-comparison of results allows characterization of each combustion structure and thus of the occupation (Table S14).

Few charcoal macro-remains were recovered inside TVII combustion areas, which we interpret as evidence of post-depositional processes and especially cleaning 
activities (Piquè 1999). Exceptions were AC3 and AC5, the latter being the structure with more macro fragments inside. On the contrary, AC7 was completely empty of charcoal remains. Results concerning degradation of n-alkane fraction are coherent with the previous assumption that intensity of use of the combustion area is negatively correlated with frequency of in situ macro combustion residues (i.e. few charcoal fragments may indicate greater intensity of cleaning activities).

Lanashuaia I provides the opportunity to study the combustion structures from a spatial perspective (Fig. 4). In that sense, fatty acids results of central combustion area (LANA3) indicate marine mammal consumption in opposition to fish consumption in LANA1, at the hut entrance, and LANA2, the open-air rear hearth. LANA1 presents high levels of coprostanol, indicating organic matter contribution and post-depositional alteration from earthworm activity. It should be noted that this combustion area was covered by shell-midden. Interestingly, although low thermal degradation of n-alkanes is observed in LANA3, burnt soil has considerable thickness (Fig. 3c). Based on that, is possible to suggest a very low-temperature but continued use of the central combustion area over the entire occupation span. As in TVII, no charcoals were found inside the central hearth (Piquè 1999: 241). Furthermore, charcoal remains and small heated pebbles where found spread over all the base of the anthropogenic deposits, indicating that cleaning and maintenance activities of central area were carried out over the entire occupation span.

\section{Heated stone accumulations}

We are going to discuss results from the fatty soil of one of the three heated stone accumulation (LANA4) and from the heated stone themselves recovered at Lanashuaia. Contrary to the other LI samples, results of LANA4 indicate a high thermal alteration. Concerning fatty acids, squalene and diploptene are present. More compelling is the significant presence of phytanic acid (Fig. 5). Phytanic acid can occur in both terrestrial (ruminant) and aquatic context (Lucquin et al. 2016a). In a Yamana context, thus, phytanic acid could indicate either guanaco or whale origin. However, a possible marine origin for LANA4 sample is also suggested by the presence of pristanic and Methyl 4,8,12-trimethyltridecanoate acids (4,8,12-TMDT) (Ackman et al. 1968; Craig et al. 2013; Farrell et al. 2014; Hansel et al. 2004; Lucquin et al. 2016b), presence 
of a series of monounsaturated fatty acids $\left(\mathrm{C}_{16: 1}\right.$ to $\left.\mathrm{C}_{22: 1}\right)$ (Patrick et al 1985 , Brown and Heron 2005), along with (minor) presence of short chain dicarboxylic acids.

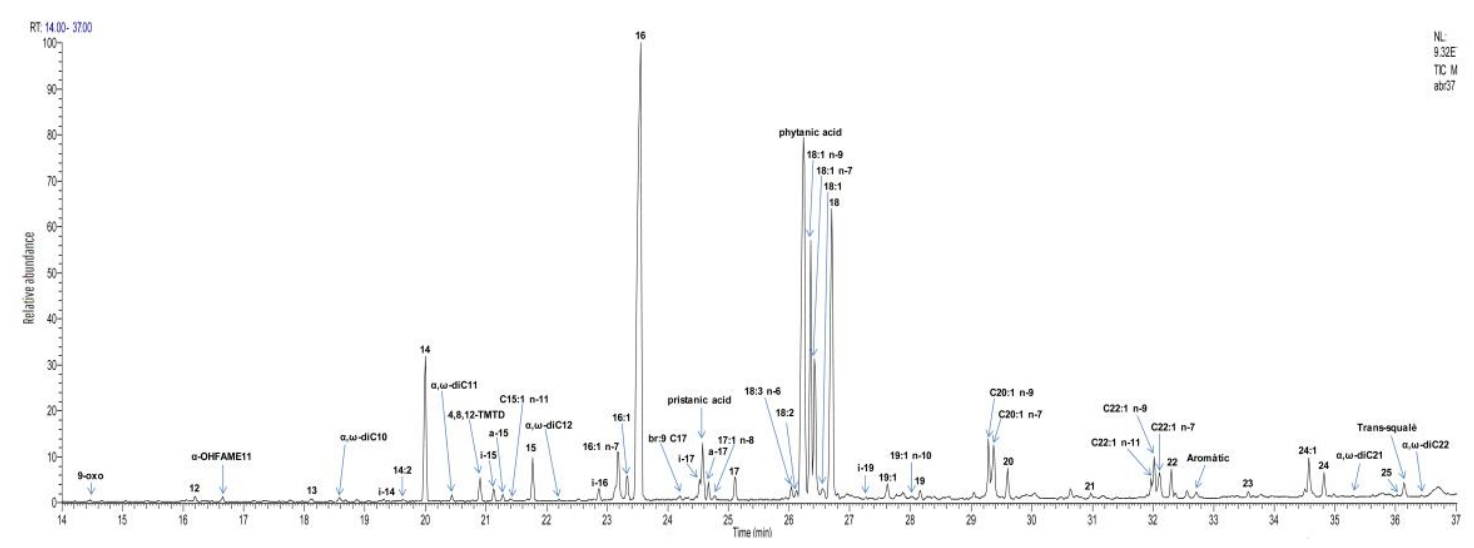

Figura 5. Mass chromatogram of the acidic fraction of soil sample LANA4 from Lanashuaia I.

The study of the heated stone samples supports these results and provides further information. The 79 beach pebble sample was characterized by homogenous size (6-14 $\mathrm{cm}$ of diameter) and a varied composition (65\% rhyolites, $15 \%$ schist, $10 \%$ granites, and $10 \%$ quartz). In 22 samples (28\%) was observed a fatty and oily adherence that sometimes had penetrated the stone following fissures or through their natural porosity. This adherence was present as a black solid product $(0,5$ to $1 \mathrm{~mm}$ of thickness) that smells particularly when it was scraped to sample, and in some cases these residues had an unctuous and fat texture that impregnated instruments used for the study. Some of the stones $(45 \%)$ present oxidized surfaces and thermal - fractures that indicates their thermal alteration at more than $500^{\circ} \mathrm{C}$ by comparison with experimental fire structures and laboratory results. Therefore, results suggest that these pebbles were chosen by their form and size, some of them were heated at high temperatures at direct fire and they were used for cooking animal fats. The cooking procedures led to the formation of a fatty-oily residue that coats these stones and contaminated the soil were these pebbles were abandoned.

The study of the acids fraction shows a very high concentration of phytanic acid and recurrence of pristanic and Methyl 4,8,12-trimethyltridecanoate acids in minor proportions (Fig. 6). These branched fatty acids were accompanied by a dominance of short fatty acids essentially Palmitic, (C16), Stearic (C18), and Myristic (C14) acids. C20, C22 and C24 and their respective mono unsaturated acids are also often present in 
minimal amounts. As state above, this evidence could indicate a possible maritime origin for these samples.

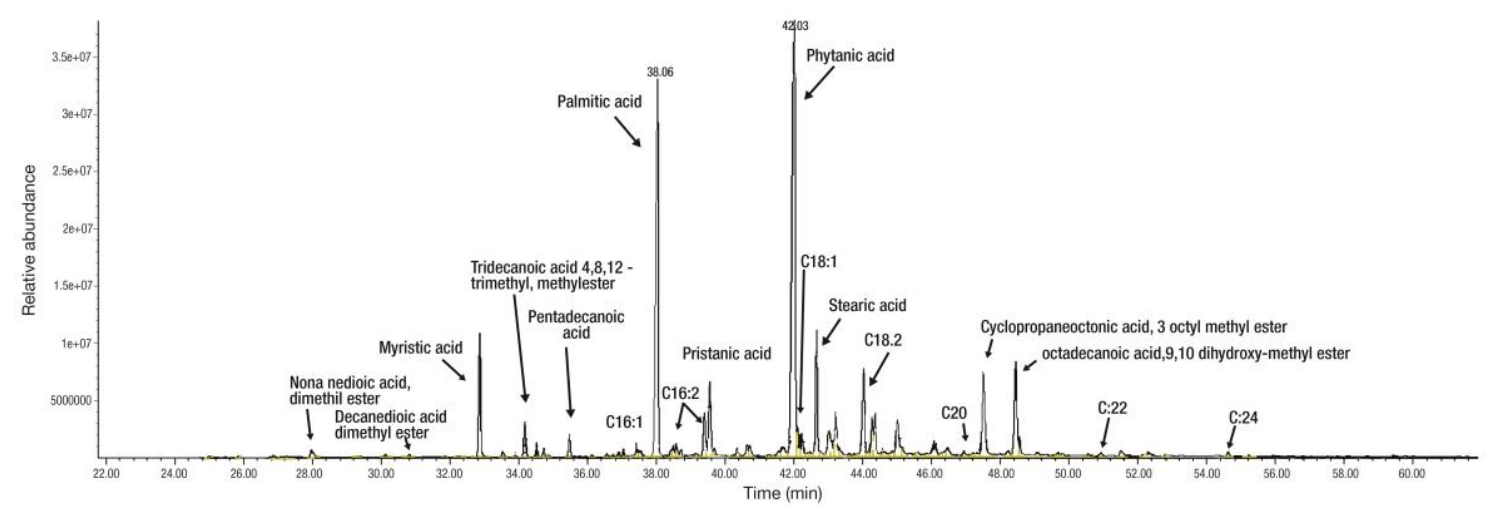

Figura 6. Mass chromatogram of the acidic fraction of pebble Sample LA36 external from Lanashuaia I.

To be more confident in our results we have taken the isotopic $\delta^{13} \mathrm{C}$ value of the phytanic acid present in the fatty oil residues on 22 samples from 11 stones (exterior and interior part was sampled apart). The mean value obtained for 15 samples of this acid is $-19,83 \%$, that is more elevated compared with the mean values of Palmitic (C16:0) and Stearic acids (C18:0) (-22,20\%o and -22,13\%o respectively), also indicating a marine origin of this acid (Table S15). Similarly, $\mathrm{C}_{18} \omega$-(o-alkylphenyl)alkanoic acids are absent. The presence of these acids was previously found in artic cemented sands from ancient hearth contexts (Buonasera et al 2015). Their absence here could be related to preservation problems, but their presence was experimentally associated to frying at temperatures greater than $270^{\circ} \mathrm{C}$ in open vessels (Hansel et al. 2004, Evershed et al. 2008 Buonasera et al. 2015). This could be related also to the cooking procedure where the stones could be in contact with fat residues at temperatures that are lower but sufficient to cook, but further experimental work must be done. Results prove that the penetration into pebbles of the residue must have occurred when pebbles were still hot.

The absence of the maritime biomarkers in some of the stones could indicate also the possibility of cooking terrestrial mammals such as guanacos. However, GC-CIRMS results confirm the maritime origin of fatty-oily residue that coats most samples: $90 \%$ of the studied samples fall into the range of marine species maritime $(95 \%$ confidence ellipses) published by Craig et al. (2011). Only two samples do not fall into this interval but are always distant from samples of terrestrial origin (Fig. 7, and Table S15). Moreover, these samples are very different from a sample coming from TUNEL 
D80 E fire structure of the near site of Túnel I (March 1999) that has shown also a maritime isotopic signature.

Unfortunately, there is no specific isotopic value for Minke whale. However, the high levels of phytanic acids are an indicator of their origin: phytanic acid is mentioned in higher proportions in whales. Antarctic and North Atlantic fin whale oils could be distinguished, the former having very low levels of 4,8,12-trimethyltridecanoic acid relative to 3,7,11,15-tetramethylhexadecanoic (phytanic) acid (Ackman et al 1968). Goffredi et al. (2005) have published isotopic values of fatty acids of whale bones in symbiotic relation with Osedax frankpressi that presented enriched values very near to the values observed here for phytanic acid. Therefore, taking that ethnographic data (March 1999) mentioned the use of heated stones by Yamana groups to melt whale blubber fats, it seems reasonable to hypothesize that this fatty oily-residue comes from the cooking treatment and the posterior bacterial degradation of Minke whale meat or blubber.

Fatty acids results of heated stones and LANA4 support previous archaeological data of LI suggesting a single long-lasting occupation initially related to the processing of a whale, probably a young Antarctic minke whale (Verdún et al. 2015). Oxygen isotopic analyses and readings of growth increments suggest that Nacella magellanica was collected predominantly in autumn-winter (Colonese et al. 2011; Verdún-Castelló 2014), which agrees well with fauna-derived seasonal data. Notwithstanding, bird and fish exploitation is also documented in spring-summer (Piana et al. 2000: 459). Ethnography reports sporadic Yamana occupations spanning several months after summer mass strandings of Fuegian sardines or especially by the encounter of a stranded whale. In the latter, the sending of smoke signals to report the finding has been described (cf. Orquera and Piana 1999). This may be a good explanation for the identification of Drimys winteri at the shell midden base, i.e. at the beginning of the occupation (Piquè 1999). According to Gusinde (1986: 379) Drimys was avoided because of heavy smoke production inside the hut. Therefore, open-air fireplace ACB11 (and nearby EC2) could be related to signal sending, being later re-used for other activities. 


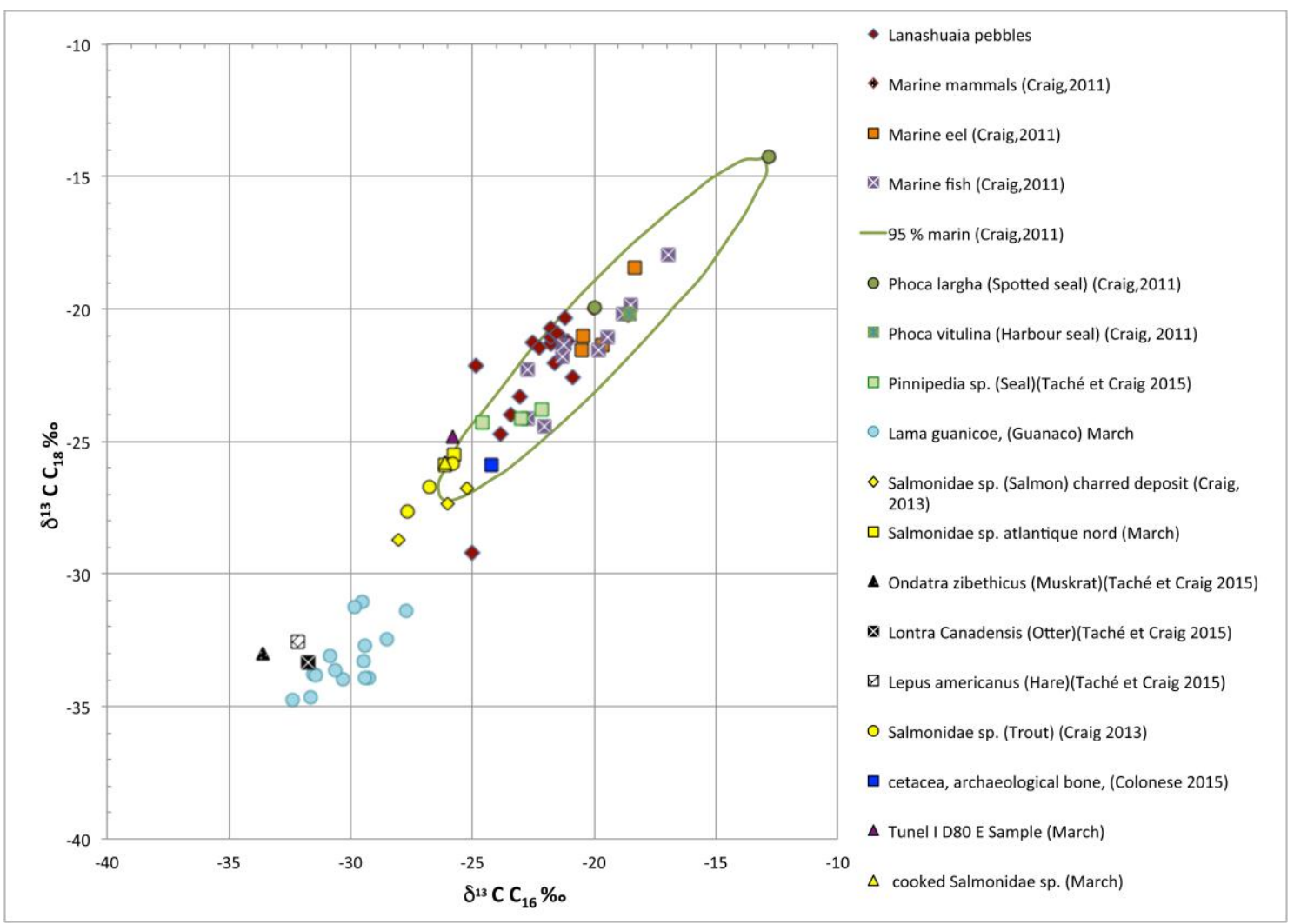

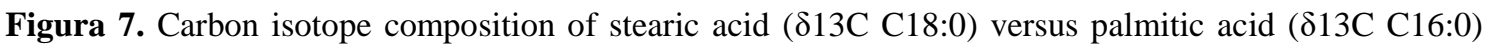
from Lanashuaia I pebbles samples and modern maritime and terrestrial animal samples (Craig et al. 2011, 2015; Taché and Craig 2015), bone archaeological samples (Colonese et al. 2015). Túnel D80E fire structure, Sample and charred or cook salmonoides.

Finally, ethnographic data supports archaeological results concerning site reoccupation and hut emplacement taking advantage of a feature of the natural relief. Important cleaning activities and space management, as well as central placement of fireplaces, are archaeologically documented in TVII and LI. Hearths at the hut entrance are also documented in LI (LANA1), and possibly in two occupations of TVII (Fig. 8), either as low-intensity combustion structures or associated with large-trunk combustion areas. However, archaeological evidence at both sites indicates more flexibility in firewood procurement than described by ethnographers, with presence of high-quality fuels (Maytenus magellanica, Berberis ilicifolia) but an important increase of lowquality fuels (Nothofagus pumilio, N. betuloides) as the occupation lengthens (Piquè, 1999). Intensity of archaeological fireplaces also differs from ethnographic observations. At LI, as well as at TVII early occupations, some of the analyzed combustion areas (AC10, AC8, AC7) evidence intensity of fire or high temperatures. They are not the only cases. In the nearby site Shamakush $X$ the minimal duration of a 
fireplace has been calculated to be 50 days, with temperatures higher than $950{ }^{\circ} \mathrm{C}$ (March et al. 1989).

Occupation $\mathrm{H}$
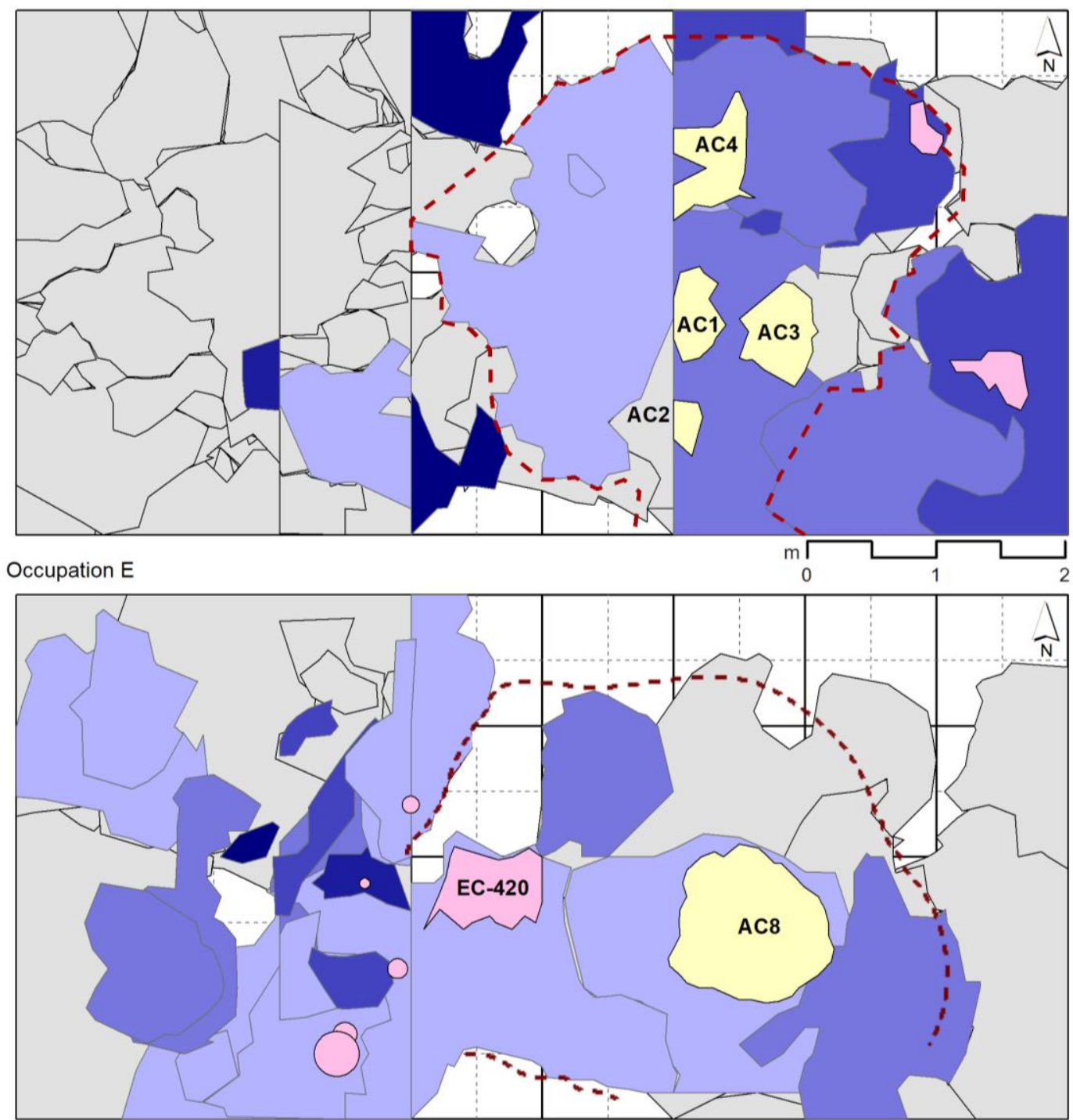

- $\square \square \square+$ + Subunit density (Number of charcoal fragments / Sediment volume)

Shell midden from previous occupations

$\mathrm{AC}$ EC - - - Hut wall

Figura 8. Spatial representation of the combustion structures and residues of Túnel VII occupations $H$ (above) and $\mathrm{E}$ (below). Note that AC2 is facing the entrance hut (South) and EC-420 (E) is facing an ostensibly entrance hut (West).

\section{Conclusions}

Lanashuaia I or Túnel VII settlement dynamics are neither related to a cyclical seasonal pattern, nor to changes in the environment, but to what has been called an “opportunistic specialization” regarding resource exploitation (Estévez and Vila, 2006). 
Yamana people adopted a wide range of strategies by means of a wide range of specialized and curated tool kits to adjust to small environmental variations in space and time. Not surprisingly, therefore, fireplace and combustion element associations indicate variability in fire-related activities, from fuel management and cleaning to fire and food processing. The flexibility of the use of fire as a tool mirrors the flexibility of other tools and hunting weapons (Mameli et al. 2005). However, ethnographic and archaeological recurrences, like hearth placement in the center or the entrance of the hut, reflect the existence of certain norms.

In sum, organic residue data, supported by archaeological and ethnographic data, allow interpretation of combustion structures from the perspective of food preparation activities and intensity of use and inform us about post-depositional factors (e.g. earthworm bioturbation). Repeated occupation of the same site over a long period of time, as well as the taphonomic processes that acted after site abandonment, generates palimpsests that are extremely difficult to solve without appropriate and interdisciplinary methodology. Those processes cannot be observed in a "Living etnoarchaeology" research and that obscures the interpretation of events in the archaeological record of the past. On the other hand, the considerable chemical variability presented in this paper forces adoption of a multidisciplinary approach to characterize each combustion structure and reconstruct the whole fire-related management strategies, from firewood procurement to fire use, cleaning activities and post-depositional history. Based on the positive results concerning the molecular and fatty acid isotopic composition of the heated stone samples from Lanashuaia site, further research will extend this analysis to samples from TVII and LI fireplaces. Moreover, assumptions about the social implications of sexual division of labor regarding fire production and maintenance cannot be answered by the isolated study of fireplaces. Further research on this topic involves the development of a broader analytical approach concerning all the evidence recovered in each site.

\section{Acknowledgments}

We would like to thank Carolina Mallol and Auréade Henry for inviting us to participate in this special volume. We would also like to thank the two anonymous reviewers for their helpful comments, which helped to improve this manuscript. 


\section{Declaration of interest statement}

The authors declare no conflict of interest.

\section{References}

Aceves, M., J. O. Grimalt, J. Albaigés, F. Broto, L. Comellas, M. Gassiot. 1988. "Analysis of hydrocarbons in aquatic sediments: II. Evaluation of common preparative procedures for petroleum and chlorinated hydrocarbons." Journal of Chromatography 436: 503-509.

Ackman, R. G., and S. N. Hooper. 1968. "Examination of Isoprenoid Fatty Acids as Distinguishing Characteristics of Specific Marine Oils with Particular Reference to Whale Oils." Comparative Biochemisty and Physiology 24 (2): 549-565.

Balbo, A., M. Madella, I. B. Godino, M. Álvarez. 2011. "Shell midden research: An interdisciplinary agenda for the Quaternary and Social Sciences." Quaternary International 239: $147-152$.

Buonasera T.Y., Tremayne, A. H. Darwent Ch.M., Eerkens, J.W, Mason O. K. 2015 "Lipid biomarkers and compound specific $\delta^{13} \mathrm{C}$ analysis indicate early development of a dual-economic system for the Arctic Small Tool tradition in northern Alaska" Journal of Archaeological Science 61:129-138

Binford, L. R. 1978. Nunamiut ethnoarchaeology. New York: Academic Press.

Brown, L.D., Heron, C.P. 2005. Presence or absence: A Preliminary study into the detection of fish oils in ceramics. In Mulville, J. and Outram, A. (eds.) The Zooarchaeology of Fats, oils, Milks and Dairying. Oxford: Oxbow Books. 67-76.

Chuecas L., J. P. Riley. 1969. "Component fatty acids of the total lipids of some marine phytoplankton." Journal of the Marine Biological Association of the United Kingdom 49: 97116.

Colonese, A.C., E. Camarós, E. Verdún, J. Estévez, S. Giralt, and M. Rejas. 2011. "Integrated Archaeozoological Research of Shell Middens: New Insights into Hunter-Gatherer-Fisher Coastal Exploitation in Tierra Del Fuego." Journal of Island \& Coastal Archaeology 6: 235254.

Colonese, A. C., TH. Farrell, A. Lucquin, D. Firth, S. Charlton, H. K. Robson, M. Alexander, and O. E. Craig. 2015. "Archaeological bone lipids as palaeodietary markers." Rapid Commun. Mass Spectrom 29: 611-618. DOI: 10.1002/rcm.7144

Craig, O. E., V. J. Steele, A. Fisher, S. Hartz, S. H. Andersen, P. Donohoe, A. Glykou, H. Saul, D. M. Jones, E. Koch, and C. P. Heron. 2011. "Ancient lipids reveal continuity in culinary practices across the transition to agriculture in Northern Europe." Proceedings of the National Academy of Sciences Nov 2011: 108 (44), 17910-17915. DOI:10.1073/pnas.1107202108

Craig, O.E., H. Saul, A. Lucquin, Y. Nishida, K. Taché, L. Clarkes, A. Thompson, D.T. Altoft, J. Uchiyama, M. Ajimoto, K. Gibbs, S. Isaksson, C.P. Heron, P. Jordan. 2013. "Earliest evidence for pottery use." Nature 496: 351-54. DOI:10.1038/nature12109

Eerkens, J.W. 2005. "GC-MS Analysis and Fatty Acid Ratios of Archaeological Potsherds from the Western Great Basin of North America". Archaeometry 47 : 83-102.

Eglinton, G., and R. J. Hamilton. 1967. "Leaf epicuticular waxes.” Science 156: 1322-1335.

Estévez, J., and L. Mameli. 2000. "Muerte en el Canal: Experiencias bioestratinómicas controladas sobre la acción sustractora de cánidos." Archaeofauna 9: 7-16. 
Estévez, J., and A. Vila, eds. 1995. Encuentros en los conchales fueguinos. Bellaterra: UABCSIC.

Estévez, J., and Vila, A. 2006. "Variability in the lithic and faunal record through 10 reoccupations of a XIX century Yamana Hut." Journal of Anthropological Archaeology 25(4): 408-423.

Estévez, J., and A. Vila. 2007. "Twenty years of ethnoarchaeological research in Tierra del Fuego: some thoughs for european shell middens archaeology." In Shell Middens in Atlantic Europe, edited by M. Milner, O.E. Craig, and G.N. Bailey, 183-195. Oxbow Books: Oxford.

Estévez, J., and I. Clemente. 2013. "Domestic Space: Analysis of the Activities of a HunterGatherer Social Unit in the Southern end of the American Continent." In The Archaeology Of Household, edited by M. Madella, G. Kovacs, B. Kulcsarne-Berzsenyi, and I. Briz i Godino, 67-85. Oxbow Books: Oxford.

Estévez, J., N. Juan-Muns, J. Martínez, R. Piqué, and A. Schiavini. 1995. "Zooarqueología y antracología: estrategias de aprovechamiento de los recursos animales y vegetales en Túnel VII" In Encuentros en los conchales fueguinos, edited by J. Estévez, and A. Vila, 143-238. Bellaterra: CSIC-UAB.

Estévez, J., A. Vila, and X. Terradas. 2002. "The island factor: Insularity as a variable in the Archaeological studiy of the social dynamics of hunter-gatherers". In Worlds Islands in Prehistory, edited by W.H. Waldren, and J.A. Ensenyat, 107-116. BAR Publishing: Oxford.

Evershed, R. P., M. S. Copley, L. Dickson, and F.A. Hansel. 2008. "Experimental evidence for the processing of marine animal products and other commodities containing polyunsaturated fatty acids in pottery vessels." Archaeometry 50: 101-13. doi:10.1111/j.1475-4754.2007. 00368.x

Farrell, Th. F. G., P. Jordan, K. Taché, A. Lucquin, K. Gibbs, A. Jorge, K. Britton, O. E. Craig, and R. Knecht. 2014. "Specialized Processing of Aquatic Resources in Prehistoric Alaskan Pottery? A Lipid-Residue Analysis of Ceramic Sherds from the Thule-Period Site of Nunalleq, Alaska”. Arctic Anthropology 51 (1): 86-100.

García-Piquer, A., and J. Estévez. 2018. "The social use of space in a shell midden: Testing ethnoarchaeological data from Tierra del Fuego (Argentina) with intra-site spatial analyses." Journal of Archaeological Science: Reports 18 (April): 1053-1065. doi:10.1016/j.jasrep.2017.12.028

Goffredi, S. K., V. J. Orphan, G. W. Rouse, L. Jahnke, T. EMbaye, K. Turk, R. Lee, and R. C. Vrijenhoek. 2005. "Evolutionary innovation: a bone-eating marine simbiosis." Environmental Microbiology 7 (9): 1369-1378. doi:10.1111/j.1462 2920.2005.00824.x

Grimalt, J. O., and C. Saiz-Jimenez. 1989. "Lipids of soil humic acids. I. The hymatomelanic acid fraction." Science of the total Environment 81/82: 409-420.

Grimalt, J. O., P. Fernández, J. M. Bayona, and J. Albaigés. 1990. “Assessment of fecal sterols and ketones as indicators of urban sewage inputs to coastal waters." Enviromental Science \& Technology 24 (3): 357-363.

Gusinde, M. 1986. Los indios de Tierra del Fuego. Tomo II. Los Yámana. Segunda parte: La vida económica. Buenos Aires: Centro argentino de etnología americana.

Hansel, F. A., M. S. Copley, L. A. S. Madurai, and R. P. Evershed. 2004. "Thermally produced $\omega$-(o-alkylphenyl)alkanoic acids provide evidence for the processing of marine products in archaeological pottery vessels." Tetrahedron Letters 45: 2999-3002. DOI:10.1016/ j.tetlet.2004.01.111 
Harvey, H., G. Eglinton, S. C. M. O'Hara, E. D. S. Corner. 1987. "Biotransformation and assimilation of dietary lipids by Calanus feeding on a dinoflagellate." Geochimica et Cosmochimica Acta 51: 3031-3040.

Juan-Muns i Plans, N. 1993. "La pesca: alternativa econòmica pels yàmana de la costa del canal Beagle." PhD diss., Universitat Autónoma de Barcelona.

Julien, M., and C. Karlin, dirs. 2014. Un automne à Pincevent : Le campement magdalénien du niveau IV20. Paris: Société Préhistorique Française.

Leroi-Gourhan, A., and M. Brézillon. 1972. Fouilles de Pincevent : essai d'analyse ethnographique d'un habitat magdalénien (la section 36). Paris: CNRS.

Leesch, D., J. Bullinger, M.-I. Cattin, W. Müller, and N. Plumettaz. 2010. "Hearths and hearthrelated activities in Magdalenian open-air sites:_the case studies of Champréveyres and Monruz (Switzerland) and their relevance to an understanding of Upper Paleolithic site structure." In The Magdalenian in central Europe. New finds and concepts. Conference on the Magdalenian culture in central Europe, Rzeszów, 20-23 September 2005 edited by M. Połtowicz-Bobak and D. Bobak, 53-69. Rzeszów: Instytut Archeologii Uniwersytetu Reszowskiego.

Leesch, D., and J. Bullinger. 2012. "Identifying dwellings in Upper Palaeolithic open-air sites The Magdalenian site at Monruz and its contribution to analysing palimpsests". In A mind set on flint Studies in honour of Dick Stapert edited by M. Niekus, N. Barton, M. Street and T. Terberger, 165-181. Groningen: Barkhuis.

López-Martínez, C., J. O. Grimalt, B. Hoogakker, J. Gruetzner, M. J. Vautravers, and I. N. McCave. 2006. "Abrupt wind regime changes in the North Atlantic Ocean during the past 30,000-60,000 years." Paleoceanography 21: PA4215.

Lucquin, A., Colonese, A.C., Farrell, T.F.G., Craig, O.E., 2016a. Utilising phytanic acid diastereomers for the characterisation of archaeological lipid residues in pottery samples. Tetrahedron Lett. 57: 703-707.

Lucquin, A., K. Gibbs, J. Uchiyama, H. Saul, M. Ajimoto, Y. Eley, A. Radini, C. P. Heron, S. Shoda, Y. Nishida, J. Lundy, P. Jordan, S. Isaksson, and O. E. Craig. 2016b. "Ancient lipids document continuity in the use of early hunter-gatherer pottery through 9,000 years of Japanese prehistory”. PNAS 113 (15): 3991-3996. DOI:10.1073/pnas.1522908113

Malainey, M.E., Przybylski, R., Sherriff, B.L. 2001. One person's food: how and why fish avoidance may affect the settlement and subsistence patterns of hunter-gatherers. Am. Antiq. 66: $141-161$.

Mallol, C., and A. Henry. 2017. "Ethnoarchaeology of Paleolithic Fire: Methodological Considerations." Current Anthropology 58 (S16): S217-S229. DOI:10.1086/691422

Mameli, L., and J. Estévez. 2004. Etnoarqueozoología de aves: el ejemplo del extremo sur americano. Madrid: CSIC-UAB.

Mameli, L., J. A. Barceló, and J. Estévez. 2002. "The Statistics of Archeological Deformation Process. A zooarchaeological experiment." In Archaeological Informatics: Pushing the Envelope, edited by G. Burenhult, 221-230. BAR Publishing: Oxford.

Mameli, L., J. Estévez, and E. L. Piana. 2005. "Deep impact: stones in bones. Some though about the Ethno-Archaeology contrast. A view from Tierra del Fuego (extreme south of America)." In Stone tools in ethnoarchaeological contexts, edited by X. Terradas, 9-19. BAR Publishing: Oxford.

March, R.J. 1988. Informe preliminar de beca de iniciación: Aplicación de métodos físicos y químicos a la determinación de pautas de conducta humanas vinculadas con la utilización del 
fuego. Consejo Nacional de Investigaciones Científicas y Técnicas. Scientific report presented to CONICET Argentine: $375 \mathrm{p}$.

March, R. J. 1995. "L'étude des structures de combustion en archéologie : un détour vers l'histoire." Annales de la Revue Fyssen 10: 53-68.

March, R.J., 1999. Chimie organique appliquée à l'étude des structures de combustion du site de Tunel I (Terre de Feu, Argentine). Revue d'archéométrie 23, 127-156.

March, R. J., and G. Wünsch. 2003. "Loupes et lentilles obscures : à propos de la fonction des structures de combustion." In Le feu domestique et ses structures au néolithique et aux âges des métaux. Actes du colloque Bourg-en-bresse 7 et 8 Octobre 2000 Beaune (France) edited by Frère Sautôt, 311-318. Montagnac: Editions Monique Mergoil.

March, R., A. Baldessari, J.-C. Ferreri, A. Grande, E. -G. Gros, O. Morello, and R. Rodano 1989. "Étude des structures de combustion archéologiques d'Argentine." Bulletin de la Société préhistorique française 10-12: 384-392. doi: 10.3406/bspf.1989.9896

March, R. J., and J. C. Ferreri. 1989. "Sobre el estudio de estructuras de combustión arquelógicas mediante replicaciones y modelos numéricos." In Nature et Fonction des foyers préhistoriques. Actes du colloque international de Nemours (1987) edited by M. Olive and Y. Taborin, 59-69. Nemours: APRAIF.

March, R. J., G. Dumarçay, A. Lucquin, and D. Joly. 2006. "Les activités liées à l'utilisation du feu. De la gestion des déchts de combustion à l'organistaion de l'espace." In Un dernier hiver à Pincevent : Les Magdaléniens du niveau IVO (Pincevent, La Grande-Paroisse, Seine-et-Marne) edited by P. Bodu, M. Julien, B. Valentin, and G. Debout, 89-116. Paris: CNRS éditions.

March, R.J., A. Lucquin, D. Joly, J. C. Ferreri, and M. Muhieddine. 2014. "Processes of Formation and Alteration of Archaeological Fire Structures: Complexity Viewed in the Light of Experimental Approaches." J Archaeol Method Theory 21 (1): 1-45. DOI:10.1007/s10816-0129134-7

March, R. J., M. Morley, and R. Whallon. 2017. "Studying Neanderthal fire structures from Crvena Stijena." In Crvena Stijena in Cultural and Ecological Context: Multidisciplinary Archaeological Research in Montenegro, edited by R. Whallon, 340-449. Montenegro: National Museum of Montenegro.

McCalley, D.V., M. Cooke, G. Nickless. 1981. "Effect of sewage treatment on faecal sterols." Water Research 5: 1019-1025.

McCarthy, R.D, and A. H. Duthie. 1962. "A rapid quantitative method for the separation of free fatty acids from other lipids." Journal of Lipid Research 3: 117-119.

Orquera, L. A. 1995. "Túnel VII. La estratigrafía.” In Encuentros en los conchales Fueguinos edited by J. Estévez and A. Vila, 83-104. Bellaterra: UAB-CSIC. Bellaterra.

Orquera, L. A., and E. L. Piana. 1999. La vida social y material de los Yámana. Buenos aires: EUDEBA.

Orquera, L. A., and E. L. Piana. 1992. "Un paso hacia la resolución del palimpsesto." In Análisis Espacial en la Arqueología Patagónica, edited by L. Borrero and J. Lanata, 21-52. Buenos Aires: Búsqueda de Ayllu.

Patrick, M., de Koning, A.J., Smith, A.B. 1985. Gas liquid chromatographic analysis of fatty acids in food residues from ceramics found in the Southwestern Cape, South Africa. Archaeometry 27: 231-236. 
Piana, E. L., and L. A. Orquera. 1995. "Túnel VII. La cronología." In Encuentros en los conchales Fueguinos edited by J. Estévez and A. Vila, 83-104. Bellaterra: UAB-CSIC. Bellaterra.

Piana, E. L., and L. A. Orquera. 2010. "Shellmidden formation at the Beagle Channel (Tierra del Fuego, Argentine)." In Monumental questions: Prehistoric megaliths, mounds, and enclosures. Proceedings of the XV World Congress (Lisbon, 4-9 September 2006), edited by D. Calado, M. Baldia and M. Boulanger, 263-271. Archaeopress: Oxford.

Piana, E. L., A. Vila, L. A. Orquera and J. Estévez. 1992. Chronicles of Ona-Ashaga: Archaeology in the Beagle Channel. Antiquity 66 (252): 771-783.

Piana, E. L., J. Estévez, A. Vila. 2000. "Lanashuaia: un sitio de canoeros del siglo pasado en la costa norte del canal Beagle." In Desde el País de los Gigantes. Tomo II, 455-469. Ríos Gallegos: Universidad de la Patagonia Austral.

Piqué, R. 1999. Producción y uso del combustible vegetal: una evaluación arqueológica. Bellaterra/Madrid: Universitat Autònoma de Barcelona/Consejo Superior de Investigaciones Científicas.

Regert, M. 2011. Analytical strategies for discriminating archaeological fatty substances from animal origin. Mass Spectrom. Rev. 30: 177 -220.

Suárez-Villagran, X. 2012. "Micromorfología de sitios concheros de América del Sur: arqueoestratigrafía y procesos de formación de sambaquis (Santa Catarina, Brasil) y concheros de Tierra del Fuego, (Argentina)." PhD diss., Universitat Autónoma de Barcelona- Universidad de Sao Paulo (Brasil).

Terradas, X., Vila, A., Clemente, I., and Mansur, E. 1999. "Ethno-neglect or the contradiction between ethnohistorical sources and the archaeological record. The case of stone tools of the Yamana people (Tierra del Fuego, Argentina)." In Ethno-analogy and the reconstruction of prehistoric artefact use and production, edited by L. Owen, and M. Porr, 103-115. Tübingen: Mo Vince Verlag.

Verdún-Castelló, E. 2011. "El consum de mol.luscs en societats caçadores-recol.lectores de Tierra del Fuego (Argentina)". PhD diss., Universitat Autónoma de Barcelona.

Verdún-Castelló, E. 2014: "El consumo de moluscos en sociedades cazadoras-recolectoras de Tierra del Fuego (Argentina)." In Cazadores de mar y tierra. Estudios recientes en arqueología fueguina edited by J. Oría and A. Tivoli, 363-387. Ushuaia: Ed. Cultural de Tierra del Fuego.

Verdún, E., I. B. Godino, E. Camarós, A. C. Colonese, J. Estévez and D. Zurro. 2010. "Metodología de excavación y análisis de concheros: experiencias acumuladas después de 20 años de estudios etnoarqueológicos en la costa norte del Canal Beagle (Tierra de Fuego, Argentina)." Férvedes 6: 25-32.

Verdún, E., J. Estévez, and A. Vila. 2015. "Ethnoarcheology of Tierra del Fuego hunter-fishergatherer societies. The site of Lanashuaia." In Forgotten times and spaces: New perspectives in paleoanthropological, paleoetnological and archeological studies, edited by S. Sázelová, M. Novák, and A. Mizerová, 532-541. Brno: Institute of Archeology of the Czech Academy of Sciences, Masaryk University.

Vila, A. 2006. "Propuesta de evaluación de la metodología arqueológica." In Etnoarqueologia de la prehistoria: más allá de la analogía. Treballs d’Etnoarqueologia, edited by A. Vila, 6176. Madrid: CSIC.

Vila, A., and J. Estévez. 2000. "Calibrando el método: arqueología en Tierra del Fuego." Archeologia Postmedievale 4: 199-207. 
Vila, A., and J. Estévez. 2017. "(IMF) PROETNO: Los proyectos etnoarqueológicos en Tierra del Fuego." DIGITAL.CSIC, November 21. http://hdl.handle.net/10261/157511 and http://hdl.handle.net/10261/157512

Vila, A., I. Clemente, X. Terradas, and E. Mansur. 1995. "La larga marcha: de roca a instrumento." In Encuentros en los conchales fueguinos, edited by J. Estévez and A. Vila, 261273. Bellaterra/Madrid: CSIC/UAB.

Vila, A., J. Estévez, E. Piana, M. Madella, J. A. Barceló, D. Zurro, I. Clemente et al. 2009. "Microstratigraphy of shell middens of Tierra del Fuego." In Humans: Evolution and Environment, edited by M. Coutinho Afonso and G. Bailey, 109-118. Archaeopress: Oxford.

Villagran, X.S., A. L. Balbo, M. Madella, A. Vila, and J. Estevez. 2011. "Experimental micromorphology in Tierra del Fuego (Argentina): Building a reference collection for the study of shell middens in cold climates." Journal of Archaeological Science 38 (3): 588-604.

Wünsch, G. 1991. "L'estudi de les associacions d'elements de combustió (AEC) en el marc de l'anàlisi de les interrelacions espacials dels elements arqueològics (ANITES): una reflexió teòrico-metodològica". PhD diss. Universitat Autónoma de Barcelona.

Wünsch, G., 1995. "De la articulación espacial del registro arqueológico a la gestión del espacio social: un ejemplo de aplicación del análisis de las interrelaciones espaciales (ANITES)." In Encuentros en los conchales fueguinos, edited by J. Estévez and A. Vila, 127-142. Bellaterra: UAB-CSIC.

Yellen, J. E. 1977. "Cultural patterning in faunal remains: evidence from the ¡Kung Bushmen." In Experimental archaeology, edited by D. Ingersoll, J.E. Yellen and W. MacDonald, 271-331. New York: Columbia University Press. 